\title{
$W \mathcal{C} C^{\text {World Journal of }}$ Cardiology
}

Online Submissions: http:/ / www.wjgnet.com/1949-8462office wjc@wjgnet.com

\section{Linking inflammation and thrombosis: Role of C-reactive protein}

\author{
William P Fay
}

William P Fay, Department of Internal Medicine and Medical Pharmacology and Physiology, University of Missouri, School of Medicine, and the Research Service, Harry S. Truman Memorial Veterans Affairs Hospital, Columbia, MO 65212, United States Author contributions: Fay WP contributed solely to this paper. Supported by Merit Review Award from the Department of Veterans Affairs, research grants from the Missouri Life Sciences Research Board and NIH, No. HL57346

Correspondence to: William P Fay, MD, Department of Internal Medicine and Medical Pharmacology and Physiology, University of Missouri, School of Medicine, and the Research Service, Harry S. Truman Memorial Veterans Affairs Hospital, 5 Hospital Drive, CE344-DC095.00, Columbia, MO 65212, United States.fayw@missouri.edu

Telephone: +1-573-8822296 Fax: +1-573-8847743

Received: August 2, 2010 Revised: September 18, 2010

Accepted: September 23, 2010

Published online: November 26, 2010

\begin{abstract}
C-reactive protein (CRP) is a biomarker of inflammation. Increased plasma levels of CRP are associated with an increased risk of myocardial infarction. However, the correlation between plasma CRP concentration and atherosclerotic plaque burden is poor. Based on these observations, it has been hypothesized that CRP increases the risk of myocardial infarction by promoting thrombosis. This article reviews available data that link enhanced CRP expression to increased risk of thrombosis, with a focus on the effects of CRP on hemostasis, platelet function, and fibrinolysis. Overall, the available data support the hypothesis that CRP is an important mechanistic link between inflammation and thrombosis.
\end{abstract}

(c) 2010 Baishideng. All rights reserved.

Key words: C-reactive protein; Thrombosis; Inflamma- tion; Tissue factor; Fibrinolysis; Plasminogen activator inhibitor-1

Peer reviewers: Thorsten Kälsch, MD, Assistant Professor of Medicine, 1st Department of Medicine, University Medical Centre Mannheim, Medical Faculty Mannheim, University of Heidelberg, Theodor-Kutzer-Ufer 1-3, D-68167 Mannheim, Germany; Mustafa Yildiz, MD, PhD, Associate Professor, EC, Cardiologist, Internal Medicine Specialist and Physiologist, Department of Cardiology, Kartal Kosuyolu Yuksek Ihtisas Educational and Research Hospital, Istanbul 81410, Turkey

Fay WP. Linking inflammation and thrombosis: Role of C-reactive protein. World J Cardiol 2010; 2(11): 365-369 Available from: URL: http://www.wjgnet.com/1949-8462/full/v2/i11/ 365.htm DOI: http://dx.doi.org/10.4330/wjc.v2.i11.365

\section{INTRODUCTION}

Inflammation is defined as a localized protective reaction of tissue to irritation, injury, or infection, which is characterized by pain, redness, swelling, and loss of function. Inflammation plays a central role in the pathogenesis of atherosclerosis ${ }^{[1]}$. C-reactive protein (CRP) is an acute phase reactant plasma protein that is present in plasma of healthy humans and whose plasma concentration increases significantly during acute and chronic inflammation ${ }^{[2]}$. Several studies have demonstrated that plasma CRP concentration is independently associated with the incidence of atherothrombotic events in humans, most notably myocardial infarction ${ }^{[3,4]}$. However, whether CRP plays a causal role in atherosclerosis and its complications, or is simply an important clinical marker of inflammation and cardiovascular risk, continues to be debated ${ }^{[5]}$. Plasma CRP levels are only weakly associated with the extent of atherosclerosis in humans ${ }^{[6]}$. The Dallas Heart Study, which measured coronary artery calcification and aortic 
plaque size in $>2000$ individuals, concluded that CRP is a poor predictor of atherosclerotic burden ${ }^{[7]}$. These results are consistent with recent experiments in which CRP-transgenic mice were crossed to atherosclerosisprone, hyperlipidemic mice to test directly the hypothesis that enhanced CRP expression drives atherosclerosis formation. Although an initial report was positive ${ }^{[8]}$, two subsequent studies have found no apparent effect of CRP on atherosclerotic plaque development ${ }^{[9,10]}$, and another study has found that CRP retards atherogenesis in mice ${ }^{[11]}$. However, transgenic mice that express human CRP demonstrate accelerated thrombosis after arterial injury compared to non-transgenic control mice ${ }^{[12]}$, and administration of highly purified preparations of CRP to humans activates the blood coagulation system $^{[13]}$. These observations support the hypothesis that CRP increases the risk of ischemic vascular events, such as myocardial infarction, not by promoting atherosclerotic plaque size, but rather by activating the blood coagulation system and increasing the risk of thrombosis. The regulatory systems that control hemostasis and thrombosis, although functioning in a highly coordinated manner, can be subdivided into three major components, namely: (1) blood platelets; (2) blood coagulation proteins present in plasma and the vascular wall; and (3) the fibrinolytic system. In this article, the scientific evidence that links CRP to the regulation of each of these systems is reviewed. As a whole, the available data support the hypothesis that CRP is an important mechanistic link between inflammation and thrombosis.

\section{STRUCTURE AND BIOLOGIC ROLE OF CRP}

CRP belongs to the pentraxin family of plasma proteins $^{[2]}$. Native CRP consists of five identical subunits, each composed of 206 amino acids with a molecular weight of 23000 , which bind non-covalently to form a symmetrically shaped, pentameric molecule with a molecular weight of 118000 . Pentameric CRP can be dissociated into monomers in vitro ${ }^{[14]}$ and in vivo ${ }^{[15]}$, with pentameric and monomeric forms exerting significantly different biological effects ${ }^{[16-18]}$. CRP binds to phosphocholine residues in bacterial cell membranes, thereby playing an important role in the innate immune response by facilitating the recognition and clearance of bacteria ${ }^{[19-21]}$. CRP also binds phosphocholine residues in apoptotic eukaryotic cells and to several mammalian proteins ${ }^{[2]}$. Aggregated or ligand-bound CRP activates the complement cascade, which suggests an additional mechanism by which CRP participates in host defense ${ }^{[23]}$. CRP is synthesized predominantly in the liver, where its production is controlled by several cytokines ${ }^{[2]}$.

\section{CRP ACTIVATES VASCULAR CELLS}

CRP is detectable in the walls of diseased blood vessels, including atherosclerotic plaque ${ }^{[24,25]}$. Although vascular wall CRP can be deposited from blood ${ }^{[26]}$, CRP mRNA is detectable in the arterial wall ${ }^{[25]}$, which indicates that CRP is also produced locally, particularly within atherosclerotic plaque, in which one study has found higher CRP mRNA concentrations than those in liver tissue ${ }^{[27]}$. Macrophages within plaques produce CRP ${ }^{[27]}$. CRP mRNA and protein are present in vascular smooth muscle cells (VSMCs) within human atherosclerotic plaques, which indicates that VSMCs synthesize CRP in vivo ${ }^{[24,27]}$. Inflammatory cytokines induce CRP expression by cultured human coronary artery VSMCs ${ }^{[28]}$. Exposure of cultured vascular endothelial cells to CRP inhibits nitric oxide synthase expression and upregulates expression of interleukin-8, intercellular adhesion molecule-1, and vascular cell adhesion molecule- $1^{[29,30]}$. In addition to phosphocholine residues, CRP binds to protein receptors that are present on plasma membranes of eukaryotic cells. CRP binds to Fc $\gamma$ receptor I (Fc $\gamma$ R I CD64), a member of the $\mathrm{IgG} F \mathrm{~F}$ receptor family, which is expressed on macrophages ${ }^{[31,32]}$. Fc $\gamma \mathrm{R}$ II a (CD32), which is expressed by macrophages and platelets and plays an important role in the pathophysiology of immune-mediated thrombocytopenia, binds CRP to activate intracellular signaling pathways $^{[33-35]}$. One study has suggested that CRP binds

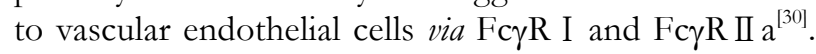
However, some studies have concluded that CRP does not bind directly to Fc $\gamma R \Pi$ a, and that the observed interactions of CRP with cells that express Fc $\gamma R$ II a might have been due to binding of the intact Fc region of antiCRP antibodies to Fc $\gamma R \Pi a^{[36]}$.

\section{EFFECT OF CRP ON BLOOD PLATELETS}

Platelets express CRP receptors Fc $\gamma$ RIII (CD16) and Fc $\gamma R$ II $a^{[37]}$. Several studies have found that CRP inhibits platelet aggregation induced by a variety of agonists, including thrombin, platelet aggregating factor (PAF), and immunoglobulin ${ }^{[38-40]}$. CRP appears to inhibit PAFinduced platelet aggregation by binding to the phosphocholine moiety of PAF ${ }^{[41]}$. However, CRP induces platelet adhesion to endothelial cells and monocytes ${ }^{[42,43]}$; interactions that promote thrombosis. The conformation of CRP (i.e. monomeric vs pentameric) might play a major role in controlling platelet aggregation. Pentameric CRP binds Fc $\gamma R$ II a on platelets, which inhibits binding of platelets to neutrophils ${ }^{[37,44]}$. Conversely, monomeric CRP binds to Fc $\gamma R$ III, which promotes platelet capture of neutrophils ${ }^{[37]}$. Activated platelets convert pentameric CRP to the monomeric form ${ }^{[44,45]}$. Hence, CRP-platelet crosstalk is bidirectional; i.e. CRP regulates platelet activation, whereas activation of platelets regulates the conformational status and biological function of CRP. Conversion of pentameric CRP to monomeric CRP by activated platelets leads to activation of monocytes, which potentially provides a mechanism to link platelet activation to monocyte activation and invasion into the vascular wall. 


\section{REGULATION OF BLOOD COAGULATION FACTORS BY CRP}

Tissue factor (TF) appears to be an important mechanistic link between inflammation, CRP, and thrombosis. TF is a 44000 molecular weight membrane-bound glycoprotein that plays a key role in initiating thrombosis after vascular injury by binding factor $\mathrm{VII}^{[46]}$. The TF-VIIa complex activates factor $\mathrm{X}$ and factor IX, thereby initiating proteolytic cascades that result in thrombin formation and blood clotting. TF is synthesized in the adventitia of normal blood vessels ${ }^{[47]}$, where it functions to maintain hemostasis after vascular trauma. TF is not detectable in the intima of normal arteries, but is abundant in the lipidrich cores of atherosclerotic plaques ${ }^{[46,48]}$. CRP stimulates TF expression by blood monocytes in vitro ${ }^{[49]}$, and it has been proposed that the monocyte is an important target cell of CRP that mediates its prothrombotic effects. CRP also induces TF expression by VSMCs, both in vitro and in $v i v 0^{[50,51]}$, which provides a mechanism by which CRP can promote fibrin formation after endothelium-denuding vascular injury.

\section{EFFECT OF CRP ON THE FIBRINOLYTIC SYSTEM}

Plasminogen is converted to plasmin, the enzyme that degrades fibrin clots, by tissue-type plasminogen activator (t-PA). Plasminogen activator inhibitor-1 (PAI-1) is the main physiological inhibitor of t-PA and urinary-type PA. PAI-1 is present in plasma, platelets, endothelial cells, VSMCs, and extracellular matrix. CRP inhibits release of t-PA and stimulates release of PAI-1 from vascular endothelial cells ${ }^{[52,53]}$. Therefore, CRP can alter the fibrinolytic balance of endothelial cells so as to promote intravascular fibrin formation.

\section{CONCLUSION}

In summary, CRP appears to play an important role in regulating the function of blood platelets, the extrinsic blood coagulation cascade, and the fibrinolytic system. In vivo, CRP enhances the thrombotic response to vascular injury. Inflammation upregulates CRP expression; hence, CRP appears to be an important mechanistic link between inflammation and thrombosis. Activation of the blood clotting system - specifically, activation of platelets - regulates CRP structure and biological function. Therefore, the CRP-dependent crosstalk between inflammation and thrombosis is bidirectional. Further studies are necessary to define more precisely the pro-thrombotic functions of CRP. In addition, more research is warranted to determine the impact on thrombosis of pharmacological inhibition of CRP expression level and function, which can be achieved with statins and compounds that specifically target $\mathrm{CRP}^{[54,55]}$.

\section{REFERENCES}

1 Ross R. Atherosclerosis--an inflammatory disease. N Engl J Med 1999; 340: 115-126

2 Pepys MB, Hirschfield GM. C-reactive protein: a critical update. J Clin Invest 2003; 111: 1805-1812

3 Ridker PM. High-sensitivity C-reactive protein and cardiovascular risk: rationale for screening and primary prevention. Am J Cardiol 2003; 92: 17K-22K

4 Ridker PM. High-sensitivity C-reactive protein, inflammation, and cardiovascular risk: from concept to clinical practice to clinical benefit. Am Heart J 2004; 148: S19-S26

5 Zacho J, Tybjaerg-Hansen A, Jensen JS, Grande P, Sillesen $\mathrm{H}$, Nordestgaard BG. Genetically elevated C-reactive protein and ischemic vascular disease. N Engl J Med 2008; 359: 1897-1908

6 Zebrack JS, Muhlestein JB, Horne BD, Anderson JL. C-reactive protein and angiographic coronary artery disease: independent and additive predictors of risk in subjects with angina. J Am Coll Cardiol 2002; 39: 632-637

7 Khera A, de Lemos JA, Peshock RM, Lo HS, Stanek HG, Murphy SA, Wians FH Jr, Grundy SM, McGuire DK. Relationship between C-reactive protein and subclinical atherosclerosis: the Dallas Heart Study. Circulation 2006; 113: 38-43

8 Paul A, Ko KW, Li L, Yechoor V, McCrory MA, Szalai AJ, Chan L. C-reactive protein accelerates the progression of atherosclerosis in apolipoprotein E-deficient mice. Circulation 2004; 109: 647-655

9 Hirschfield GM, Gallimore JR, Kahan MC, Hutchinson WL, Sabin CA, Benson GM, Dhillon AP, Tennent GA, Pepys MB. Transgenic human $\mathrm{C}$-reactive protein is not proatherogenic in apolipoprotein E-deficient mice. Proc Natl Acad Sci USA 2005; 102: 8309-8314

10 Trion A, de Maat MP, Jukema JW, van der Laarse A, Maas MC, Offerman EH, Havekes LM, Szalai AJ, Princen HM, Emeis JJ. No effect of C-reactive protein on early atherosclerosis development in apolipoprotein $E^{*} 3$-leiden/human C-reactive protein transgenic mice. Arterioscler Thromb Vasc Biol 2005; 25: 1635-1640

11 Kovacs A, Tornvall P, Nilsson R, Tegnér J, Hamsten A, Björkegren J. Human C-reactive protein slows atherosclerosis development in a mouse model with human-like hypercholesterolemia. Proc Natl Acad Sci USA 2007; 104: 13768-13773

12 Danenberg HD, Szalai AJ, Swaminathan RV, Peng L, Chen Z, Seifert P, Fay WP, Simon DI, Edelman ER. Increased thrombosis after arterial injury in human C-reactive proteintransgenic mice. Circulation 2003; 108: 512-515

13 Bisoendial RJ, Kastelein JJ, Levels JH, Zwaginga JJ, van den Bogaard B, Reitsma PH, Meijers JC, Hartman D, Levi M, Stroes ES. Activation of inflammation and coagulation after infusion of C-reactive protein in humans. Circ Res 2005; 96: 714-716

14 Kresl JJ, Potempa LA, Anderson BE. Conversion of native oligomeric to a modified monomeric form of human C-reactive protein. Int J Biochem Cell Biol 1998; 30: 1415-1426

15 Diehl EE, Haines GK 3rd, Radosevich JA, Potempa LA. Immunohistochemical localization of modified C-reactive protein antigen in normal vascular tissue. Am J Med Sci 2000; 319: 79-83

16 Devaraj S, Venugopal S, Jialal I. Native pentameric C-reactive protein displays more potent pro-atherogenic activities in human aortic endothelial cells than modified C-reactive protein. Atherosclerosis 2006; 184: 48-52

17 Heuertz RM, Schneider GP, Potempa LA, Webster RO. Native and modified C-reactive protein bind different receptors on human neutrophils. Int J Biochem Cell Biol 2005; 37: 320-335 
18 Khreiss T, József L, Potempa LA, Filep JG. Conformational rearrangement in C-reactive protein is required for proinflammatory actions on human endothelial cells. Circulation 2004; 109: 2016-2022

19 Szalai AJ, VanCott JL, McGhee JR, Volanakis JE, Benjamin WH Jr. Human C-reactive protein is protective against fatal Salmonella enterica serovar typhimurium infection in transgenic mice. Infect Immun 2000; 68: 5652-5656

20 Szalai AJ, Briles DE, Volanakis JE. Human C-reactive protein is protective against fatal Streptococcus pneumoniae infection in transgenic mice. J Immunol 1995; 155: 2557-2563

21 Xia D, Samols D. Transgenic mice expressing rabbit C-reactive protein are resistant to endotoxemia. Proc Natl Acad Sci USA 1997; 94: 2575-2580

22 Chang MK, Binder CJ, Torzewski M, Witztum JL. C-reactive protein binds to both oxidized LDL and apoptotic cells through recognition of a common ligand: Phosphorylcholine of oxidized phospholipids. Proc Natl Acad Sci USA 2002; 99: 13043-13048

23 Jiang H, Robey FA, Gewurz H. Localization of sites through which C-reactive protein binds and activates complement to residues 14-26 and 76-92 of the human C1q A chain. J Exp Med 1992; 175: 1373-1379

24 Jabs WJ, Theissing E, Nitschke M, Bechtel JF, Duchrow M, Mohamed S, Jahrbeck B, Sievers HH, Steinhoff J, Bartels C. Local generation of $\mathrm{C}$-reactive protein in diseased coronary artery venous bypass grafts and normal vascular tissue. Circulation 2003; 108: 1428-1431

25 Kobayashi S, Inoue N, Ohashi Y, Terashima M, Matsui K, Mori T, Fujita H, Awano K, Kobayashi K, Azumi H, Ejiri J, Hirata K, Kawashima S, Hayashi Y, Yokozaki H, Itoh H, Yokoyama M. Interaction of oxidative stress and inflammatory response in coronary plaque instability: important role of C-reactive protein. Arterioscler Thromb Vasc Biol 2003; 23: 1398-1404

26 Sun H, Koike T, Ichikawa T, Hatakeyama K, Shiomi M, Zhang B, Kitajima S, Morimoto M, Watanabe T, Asada Y, Chen YE, Fan J. C-reactive protein in atherosclerotic lesions: its origin and pathophysiological significance. Am J Pathol 2005; 167: 1139-1148

27 Yasojima K, Schwab C, McGeer EG, McGeer PL. Generation of C-reactive protein and complement components in atherosclerotic plaques. Am J Pathol 2001; 158: 1039-1051

28 Calabró P, Willerson JT, Yeh ET. Inflammatory cytokines stimulated C-reactive protein production by human coronary artery smooth muscle cells. Circulation 2003; 108: 1930-1932

29 Venugopal SK, Devaraj S, Yuhanna I, Shaul P, Jialal I. Demonstration that C-reactive protein decreases eNOS expression and bioactivity in human aortic endothelial cells. Circulation 2002; 106: 1439-1441

30 Devaraj S, Du Clos TW, Jialal I. Binding and internalization of C-reactive protein by Fcgamma receptors on human aortic endothelial cells mediates biological effects. Arterioscler Thromb Vasc Biol 2005; 25: 1359-1363

31 Crowell RE, Du Clos TW, Montoya G, Heaphy E, Mold C. C-reactive protein receptors on the human monocytic cell line U-937. Evidence for additional binding to Fc gamma RI. J Immunol 1991; 147: 3445-3451

32 Mold C, Rodriguez W, Rodic-Polic B, Du Clos TW. C-reactive protein mediates protection from lipopolysaccharide through interactions with Fc gamma R. J Immunol 2002; 169: 7019-7025

33 Bharadwaj D, Stein MP, Volzer M, Mold C, Du Clos TW. The major receptor for C-reactive protein on leukocytes is fcgamma receptor II. J Exp Med 1999; 190: 585-590

34 Chi M, Tridandapani S, Zhong W, Coggeshall KM, Mortensen RF. C-reactive protein induces signaling through
Fc gamma RIIa on HL-60 granulocytes. J Immunol 2002; 168: 1413-1418

35 Stein MP, Edberg JC, Kimberly RP, Mangan EK, Bharadwaj D, Mold C, Du Clos TW. C-reactive protein binding to FcgammaRIla on human monocytes and neutrophils is allelespecific. J Clin Invest 2000; 105: 369-376

36 Saeland E, van Royen A, Hendriksen K, Vilé-Weekhout H, Rijkers GT, Sanders LA, van de Winkel JG. Human C-reactive protein does not bind to FcgammaRIIa on phagocytic cells. J Clin Invest 2001; 107: 641-643

37 Filep JG. Platelets affect the structure and function of C-reactive protein. Circ Res 2009; 105: 109-111

38 Cheryk LA, Hayes MA, Gentry PA. Modulation of bovine platelet function by C-reactive protein. Vet Immunol Immunopathol 1996; 52: 27-36

39 Filep JG, Hermán F, Kelemen E, Földes-Filep E. C-reactive protein inhibits binding of platelet-activating factor to human platelets. Thromb Res 1991; 61: 411-421

40 Fiedel BA, Gewurz H. Effects of C-reactive protein on platelet function. I. Inhibition of platelet aggregation and release reactions. J Immunol 1976; 116: 1289-1294

41 Kilpatrick JM, Virella G. Inhibition of platelet-activating factor by rabbit C-reactive protein. Clin Immunol Immunopathol 1985; 37: 276-281

42 Yaron G, Brill A, Dashevsky O, Yosef-Levi IM, Grad E, Danenberg HD, Varon D. C-reactive protein promotes platelet adhesion to endothelial cells: a potential pathway in atherothrombosis. Br J Haematol 2006; 134: 426-431

43 Danenberg HD, Kantak N, Grad E, Swaminathan RV, Lotan C, Edelman ER. C-reactive protein promotes monocyteplatelet aggregation: an additional link to the inflammatorythrombotic intricacy. Eur J Haematol 2007; 78: 246-252

44 Khreiss T, József L, Potempa LA, Filep JG. Opposing effects of C-reactive protein isoforms on shear-induced neutrophilplatelet adhesion and neutrophil aggregation in whole blood. Circulation 2004; 110: 2713-2720

45 Eisenhardt SU, Habersberger J, Murphy A, Chen YC, Woollard KJ, Bassler N, Qian H, von Zur Muhlen C, Hagemeyer CE, Ahrens I, Chin-Dusting J, Bobik A, Peter K. Dissociation of pentameric to monomeric C-reactive protein on activated platelets localizes inflammation to atherosclerotic plaques. Circ Res 2009; 105: 128-137

46 Marmur JD, Thiruvikraman SV, Fyfe BS, Guha A, Sharma SK, Ambrose JA, Fallon JT, Nemerson Y, Taubman MB. Identification of active tissue factor in human coronary atheroma. Circulation 1996; 94: 1226-1232

47 Wilcox JN, Smith KM, Schwartz SM, Gordon D. Localization of tissue factor in the normal vessel wall and in the atherosclerotic plaque. Proc Natl Acad Sci USA 1989; 86: 2839-2843

48 Thiruvikraman SV, Guha A, Roboz J, Taubman MB, Nemerson Y, Fallon JT. In situ localization of tissue factor in human atherosclerotic plaques by binding of digoxigeninlabeled factors VIIa and X. Lab Invest 1996; 75: 451-461

49 Cermak J, Key NS, Bach RR, Balla J, Jacob HS, Vercellotti GM. C-reactive protein induces human peripheral blood monocytes to synthesize tissue factor. Blood 1993; 82: 513-520

50 Cirillo P, Golino P, Calabrò P, Calì G, Ragni M, De Rosa S, Cimmino G, Pacileo M, De Palma R, Forte L, Gargiulo A, Corigliano FG, Angri V, Spagnuolo R, Nitsch L, Chiariello M. C-reactive protein induces tissue factor expression and promotes smooth muscle and endothelial cell proliferation. Cardiovasc Res 2005; 68: 47-55

51 Wu J, Stevenson MJ, Brown JM, Grunz EA, Strawn TL, Fay WP. C-reactive protein enhances tissue factor expression by vascular smooth muscle cells: mechanisms and in vivo significance. Arterioscler Thromb Vasc Biol 2008; 28: 698-704

52 Devaraj S, Xu DY, Jialal I. C-reactive protein increases 
plasminogen activator inhibitor-1 expression and activity in human aortic endothelial cells: implications for the metabolic syndrome and atherothrombosis. Circulation 2003; 107: 398-404

53 Singh U, Devaraj S, Jialal I. C-reactive protein decreases tissue plasminogen activator activity in human aortic endothelial cells: evidence that C-reactive protein is a procoagulant. Arterioscler Thromb Vasc Biol 2005; 25: 2216-2221

54 Albert MA, Danielson E, Rifai N, Ridker PM. Effect of statin therapy on C-reactive protein levels: the pravastatin inflammation/CRP evaluation (PRINCE): a randomized trial and cohort study. JAMA 2001; 286: 64-70

55 Pepys MB, Hirschfield GM, Tennent GA, Gallimore JR, Kahan MC, Bellotti V, Hawkins PN, Myers RM, Smith MD, Polara A, Cobb AJ, Ley SV, Aquilina JA, Robinson CV, Sharif I, Gray GA, Sabin CA, Jenvey MC, Kolstoe SE, Thompson D, Wood SP. Targeting C-reactive protein for the treatment of cardiovascular disease. Nature 2006; 440: 1217-1221

S- Editor Cheng JX L- Editor Kerr C E- Editor Zheng XM 